Provided for non-commercial research and educational use only. Not for reproduction or distribution or commercial use.

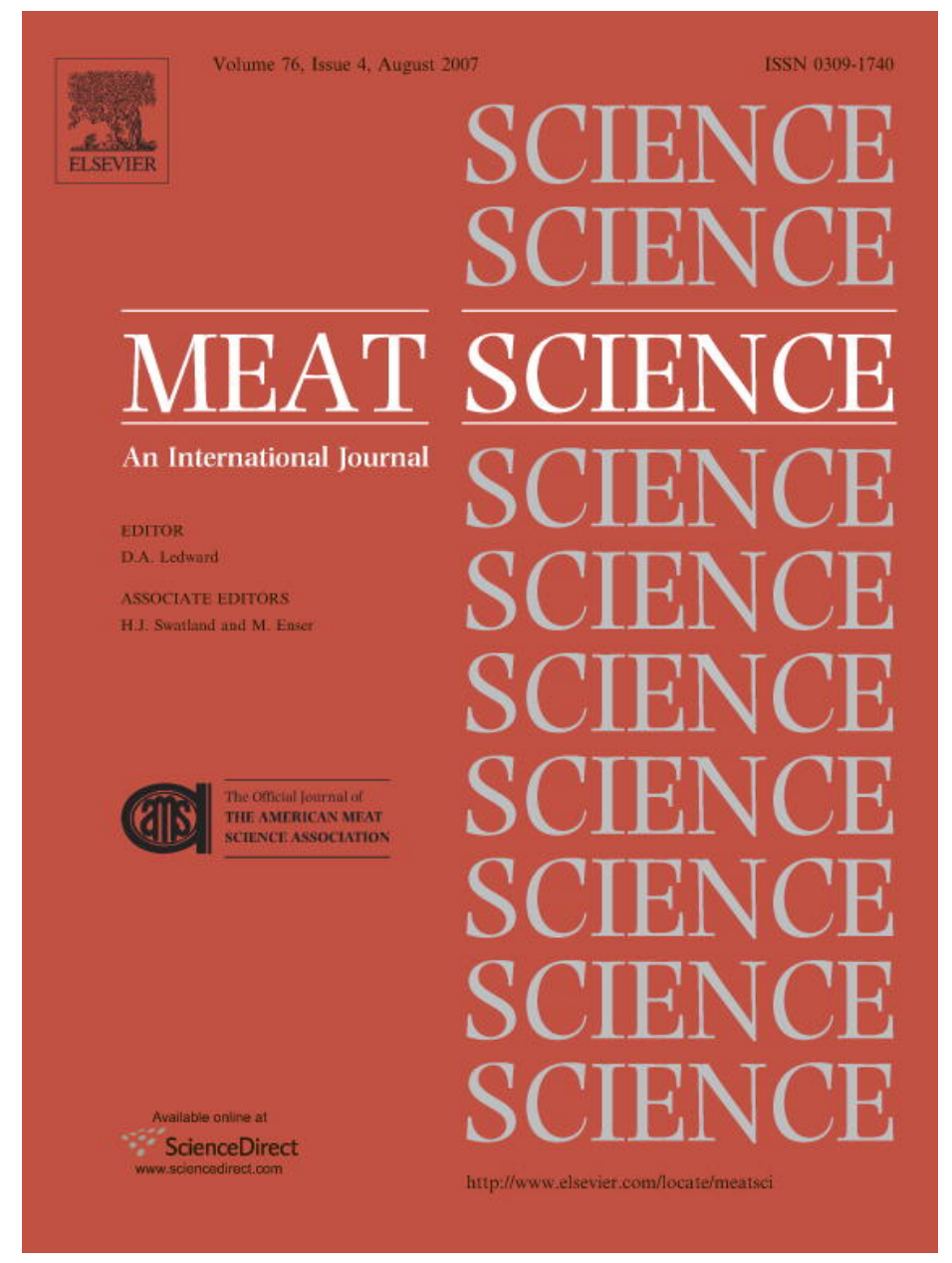

This article was originally published in a journal published by Elsevier, and the attached copy is provided by Elsevier for the author's benefit and for the benefit of the author's institution, for non-commercial research and educational use including without limitation use in instruction at your institution, sending it to specific colleagues that you know, and providing a copy to your institution's administrator.

All other uses, reproduction and distribution, including without limitation commercial reprints, selling or licensing copies or access,

or posting on open internet sites, your personal or institution's website or repository, are prohibited. For exceptions, permission may be sought for such use through Elsevier's permissions site at: 


\title{
Sheep carcass composition estimated from Longissimus thoracis et lumborum muscle volume measured by in vivo real-time ultrasonography
}

\author{
S.R. Silva *, C.M. Guedes, V.A. Santos, A.L. Lourenço, J.M.T. Azevedo, A. Dias-da-Silva \\ CECAV-Universidade de Trás-os-Montes e Alto Douro, Department of Animal Science, Apartado 1013, 5000-801 Vila Real, Portugal
}

Received 20 November 2006; received in revised form 13 February 2007; accepted 14 February 2007

\begin{abstract}
The use of Longissimus thoracis et lumborum muscle (LM) volume measured in vivo by real-time ultrasonography (RTU) to estimate carcass composition was evaluated in 47 female sheep. Animals were scanned over six sites (7th, 9th, 11th and 13th thoracic vertebrae and 2 nd and 4th lumbar vertebrae). After slaughter carcass weight (CW) and composition by dissection were determined. RTU volume measurements were calculated by multiplying the LM area at each site by the vertebra lengths. Equivalent measurements to those taken in vivo were obtained on the carcass using a digital camera and image analysis. The correlation between LM volume measured by RTU and in the carcass was high for all scans. LM volume was better in predicting carcass muscle than carcass fat. Lower determination coefficients were obtained between LM volume and carcass tissues expressed in $\%$ of $\mathrm{CW}$. The best estimates of carcass tissues weights and proportions were obtained using the LM volume between the 2 nd and the 4 th lumbar vertebrae for all tissues.

Multiple regression equations were fitted using live weight (LW) and LM volume to predict carcass composition. For all tissues, the best fit was obtained with two, three or four independent variables and the stepwise procedure was consistent in selecting LW to establish the prediction equations. Weights and proportions of muscle, subcutaneous fat, intermuscular fat and total fat were accurately predicted.

These results indicate that Longissimus thoracis et lumborum muscle volume measured in vivo by RTU can be used to predict sheep carcass composition (muscle and fat).
\end{abstract}

(C) 2007 Elsevier Ltd. All rights reserved.

Keywords: Carcass composition; Muscle; Sheep; Volume; Ultrasound

\section{Introduction}

The determination of three-dimensional structure from serial sections is a common problem in animal corporal composition studies. Among the objective techniques available, computer tomography (CT) and magnetic resonance imaging (MRI) are frequently used for in vivo three-dimensional structure determination by using consecutive images that can be reconstructed to render a volume measurement of a region of interest (Mitchell, Scholz, Wange, \& Song, 2001; Szabo et al., 1999). In addition, comprehensive studies conducted with pigs (Baulain, 1997; Mitchell et al.,

\footnotetext{
* Corresponding author. Tel.: +351 259350417; fax: +351 259350482.

E-mail address: ssilva@utad.pt (S.R. Silva).
}

2001) and lambs (Jopson, Kolstad, Sehested, \& Vangen, 1995; Kvame \& Vangen, 2006), showed that volume measured in vivo by $\mathrm{CT}$ and MRI was highly correlated $(r>0.90)$ with the weights of the dissected tissues. Thus, these techniques have been shown to be very accurate but their high cost limits their routine application in animal science (Fuller, Fowler, McNeill, \& Foster, 1994). Other techniques, such as real-time ultrasound (RTU), should be considered for volume determinations.

Ultrasound has been used for evaluating animal composition for over 40 years based on tissue depth and area measurements (Hopkins, Pirlot, Roberts, \& Beattie, 1993; McEwan, Clarke, Knowler, \& Wheeler, 1989; Silva, Gomes, Dias-da-Silva, Gil, \& Azevedo, 2005; Stouffer, Wallentine, Wellington, \& Diekmann, 1961; Teixeira, 
Matos, Rodrigues, Delfa, \& Cadavez, 2006), but little information is available about volume measurements. Results obtained with lamb (Mahgoub, 1998) and with broilers (Silva, Pinheiro, Guedes, \& Mourão, 2006) showed that muscle volume measurements obtained in vivo by RTU were able to explain carcass composition. Studies conducted by Mahgoub (1998) showed that Longissimus thoracis et lumborum muscle (LM) volume measured in vivo by RTU correlated ( $r=0.59 ; n=18)$ with LM volume determined on the carcass.

This study was undertaken to evaluate the LM volume measured in vivo by RTU as a predictor of sheep carcass muscle and fat weights and proportions.

\section{Materials and methods}

Animal handling followed the EU directive number 86/ 609/EEC concerning animal care.

\subsection{Animals and management}

The experimental group consisted of 47 female sheep from the native Churra da Terra Quente breed (41.9 \pm $6.8 \mathrm{~kg}$ ) selected from the research herd of the University of Trás-os-Montes and Alto Douro (Portugal). All animals were kept under the same management conditions and were fed according to the NRC (1985) recommendations. Prior to ultrasound measurements and subsequent slaughter, animals were shorn and deprived of food for $24 \mathrm{~h}$.

\subsection{Ultrasound measurements}

Just before slaughter, animals were scanned with an Aloka SSD 500V real-time scanner using a linear (64 $\mathrm{mm}$ ) probe of $5.0 \mathrm{MHz}$ as described by Silva, Afonso et al. (2006).

The RTU images were taken over the $7 \mathrm{th}, 9 \mathrm{th}, 11 \mathrm{th}$ and 13 th thoracic vertebrae and 2 nd and 4 th lumbar vertebrae. Once a satisfactory image had been obtained at each site, it was captured on a video printer for image analysis.

\subsection{Slaughter procedure and carcass measurements}

After RTU measurements, the live weight (LW) of all animals was recorded. All the animals were electrically stunned and slaughtered by exsanguination. The fore and the hind limbs (feet) were then separated at the radio-carpal and tarso-metatarsal articulations, respectively and the pelt, head and all internal organs were removed. After being stored at $4{ }^{\circ} \mathrm{C}$ for $24 \mathrm{~h}$ carcasses were weighed $(\mathrm{CW})$ and split down the vertebral column with a band saw. The left half of each carcass was entirely dissected into muscle, subcutaneous fat, intermuscular fat and bone, using the method described by Fisher and De Boer (1994). The weights of muscle, subcutaneous fat and intermuscular fat were recorded and their proportion in $\mathrm{CW}$ was calculated and expressed as percentages.
A segment of the thoracic/lumbar region (6th thoracic vertebra to the 5th lumbar vertebra) was removed from the right half to take carcass measurements equivalent to those taken in vivo by RTU. This segment was frozen over a horizontal surface in order to minimize muscle shape deformation and was split at each vertebra with an electric saw to expose the planes where RTU measurements were taken. After that, a digital camera was used to capture images of the planes where the carcass measurements were taken for image analysis.

\subsection{Image analysis and volume calculation}

The printed images taken after RTU measurements were digitized. The area of the LM for both RTU and carcass images, at each site, were determined after image analysis using the Image J software (http://rsb.info.nih.gov/ij/). The area was obtained by tracing the contour of the LM and by counting the number of pixels on each of the six sites. The number of pixels was then converted into area measurements corresponding to the image plane of the six sites. Six slice areas were obtained.

Scanning and interpretation of the images was always done by the same technician, with extensive experience in ultrasound technology, image interpretation, and anatomical knowledge of sheep.

The LM volume (LMV) was calculated by multiplying the slice areas obtained by in vivo RTU and carcass measurements by the slice lengths as proposed by Silva, Pinheiro et al. (2006). The slice lengths were obtained after physical measurement in vivo or in carcass, using a ruler, of the length between the sixth thoracic vertebra and the fifth lumbar vertebra and divided by six to obtain the length of each slice. The following equation was used for LM volume calculation $\left(\mathrm{cm}^{3}\right)$ :

Volume $=\sum_{i=1}^{6} A_{i} d_{i}$

where $d$ is the slice length $(\mathrm{cm}), A$ is the slice area $\left(\mathrm{cm}^{2}\right)$ and $i$ is the number of slices.

The LM total volume $\left(\mathrm{LMV}_{\text {tot }}\right)$ was calculated as the sum of the volumes of six slices: $\mathrm{LMV}_{7}, \mathrm{LMV}_{9}, \mathrm{LMV}_{11}$, $\mathrm{LMV}_{13}, \mathrm{LMV}_{2}$ and $\mathrm{LMV}_{4}$. Volumes of the LM from the 7 th to the 13th thoracic vertebrae $\left(\mathrm{LMV}_{7}-\mathrm{LMV}_{13}\right)$ and from the 2 nd to the 4 th lumbar vertebrae $\left(\mathrm{LMV}_{2}-\mathrm{LMV}_{4}\right)$ were also calculated.

\subsection{Statistical analysis}

Data were subjected to correlation and regression analysis to study relationships between carcass and RTU measurements and to estimate carcass muscle, subcutaneous fat, intermuscular fat and total fat weights and proportions. All analyses were performed with SAS software (v. 8.2; SAS Institute Inc. Cary, NC). The simple regression equations were evaluated with the determination coefficient 
$\left(R^{2}\right)$ and the residual standard deviation (RSD). A stepwise forward regression procedure was used to determine significant variables included in the equation. Best models were selected based on $R^{2}$, optimizing Mallow's $\mathrm{Cp}$ statistics and RSD (MacNeil, 1983).

\section{Results and discussion}

\subsection{Carcass composition}

Mean values, range of the values, standard error (SE) and coefficient of variation $(\mathrm{CV})$ for $\mathrm{LW}, \mathrm{CW}$ and carcass composition are presented in Table 1.

These data show that the sheep presented a large range of variation in $\mathrm{LW}$ and $\mathrm{CW}$. Carcass composition also had a large range of variation, particularly the subcutaneous fat. This was expected given the variation in LW (from 30.9 to $60.4 \mathrm{~kg}$ ) and the fact that fat is the most variable tissue in terms of proportion of body composition.

As expected the $\mathrm{CV}$ of carcass tissues, when expressed as proportions of $\mathrm{CW}$, were much lower since the conversion of these components to their proportions removes most of its variation. This is in accordance with results presented by other authors (Fortin, 1980; Shelton, Smith, \& Orts, 1977; Silva et al., 2005) using RTU with sheep.

\subsection{Carcass and ultrasound measurements}

Mean values, SE and CV for carcass and RTU measurements and the simple correlation coefficients $(r)$ between RTU and carcass LM volume are presented in Table 2.

The variation observed for all measurements is large. The LM volume increased from the 7 th thoracic vertebra to the 4th lumbar vertebra for both carcass and RTU measurements. This is expected and depends on the LM shape (Korn, Baulain, Arnold, \& Brade, 2005).

Differences between RTU and carcass measurements of LM volume were observed, the RTU measurements being

Table 1

Mean values, range of values, standard error (SE) and coefficient of variation $(\mathrm{CV}, \%)$ for live weight, carcass weight $(\mathrm{CW})$ and composition of sheep $(n=47)$

\begin{tabular}{llllr}
\hline & Mean & Range & SE & CV \\
\hline Live weight $(\mathrm{kg})$ & 41.96 & $30.9-60.43$ & 1.0 & 16.3 \\
Carcass weight $(\mathrm{kg})$ & 18.11 & $11.8-28.8$ & 0.53 & 20.0 \\
Tissue weight $(\mathrm{kg})$ & & & & \\
Muscle & 9.45 & $6.8-13.4$ & 0.19 & 13.7 \\
Subcutaneous fat & 2.92 & $0.90-6.6$ & 0.20 & 47.2 \\
Intermuscular fat & 2.26 & $0.67-4.4$ & 0.13 & 40.9 \\
Total fat & 5.18 & $1.6-10.9$ & 0.33 & 44.1 \\
Proportion (\% CW) & & & & \\
Muscle & 52.91 & $42.7-68.4$ & 0.76 & 9.8 \\
Subcutaneous fat & 15.52 & $5.1-25.1$ & 0.67 & 29.9 \\
Intermuscular fat & 12.04 & $4.4-16.9$ & 0.43 & 24.5 \\
Total fat & 27.59 & $9.5-41.9$ & 1.08 & 27.0 \\
\hline
\end{tabular}

Table 2

Mean values, standard error (SE) and coefficient of variation $(\mathrm{CV}, \%)$ for Longissimus thoracis et lumborum muscle volume (LMV) measured in vivo by real-time ultrasonography (RTU) and in the carcass of the sheep $(n=47)$ and the simple correlation coefficients $(r)$ between in vivo real-time ultrasonography (RTU) and carcass measurements

\begin{tabular}{|c|c|c|c|c|c|c|c|}
\hline \multirow[t]{2}{*}{$\operatorname{LMV}\left(\mathrm{cm}^{3}\right)$} & \multicolumn{3}{|c|}{ Carcass } & \multicolumn{3}{|c|}{ In vivo $\mathrm{RTU}$} & \multirow[t]{2}{*}{$r$} \\
\hline & Mean & SE & $\mathrm{CV}$ & Mean & SE & $\mathrm{CV}$ & \\
\hline $\mathrm{LMV}_{7}{ }^{\mathrm{a}}$ & 74.8 & 2.46 & 22.6 & 43.8 & 1.26 & 19.7 & $0.874^{*}$ \\
\hline $\mathrm{LMV}_{9}{ }^{\mathrm{a}}$ & 83.1 & 2.52 & 20.8 & 60.4 & 1.74 & 19.7 & $0.918^{*}$ \\
\hline $\operatorname{LMV}_{11}{ }^{\mathrm{a}}$ & 86.7 & 2.77 & 21.9 & 64.9 & 1.91 & 20.2 & $0.949^{*}$ \\
\hline $\mathrm{LMV}_{13}{ }^{\mathrm{a}}$ & 89.8 & 2.80 & 21.3 & 78.0 & 2.28 & 20.1 & $0.952^{*}$ \\
\hline $\mathrm{LMV}_{7}-\mathrm{LMV}_{13}{ }^{\mathrm{b}}$ & 334.4 & 9.95 & 20.4 & 247.0 & 7.16 & 19.9 & $0.951^{*}$ \\
\hline $\mathrm{LMV}_{2}^{\mathrm{a}}$ & 93.2 & 3.03 & 22.3 & 78.2 & 2.83 & 24.8 & $0.909^{*}$ \\
\hline $\mathrm{LMV}_{4}{ }^{\mathrm{a}}$ & 102.3 & 3.33 & 22.3 & 80.7 & 2.42 & 20.5 & $0.966^{*}$ \\
\hline $\mathrm{LMV}_{2}-\mathrm{LMV}_{4}{ }^{\mathrm{c}}$ & 195.5 & 6.37 & 22.3 & 158.9 & 5.10 & 22.0 & $0.963^{*}$ \\
\hline $\mathrm{LMV}_{\text {tot }}{ }^{\mathrm{d}}$ & 529.9 & 16.13 & 20.9 & 405.9 & 12.10 & 20.4 & $0.968^{*}$ \\
\hline
\end{tabular}

${ }^{\mathrm{a}} \mathrm{LMV}_{7}, \mathrm{LMV}_{9}, \mathrm{LMV}_{11}, \mathrm{LMV}_{13}, \mathrm{LMV}_{2}, \mathrm{LMV}_{4}$ : Longissimus thoracis et lumborum muscle volume above the 7th, 9th, 11th and 13th thoracic vertebrae and the 2 nd and 4 th lumbar vertebrae, respectively.

${ }^{\mathrm{b}} \mathrm{LMV}_{7}-\mathrm{LMV}_{13}$ : Longissimus thoracis et lumborum muscle volume between the $7 \mathrm{th}$ and the 13 th thoracic vertebrae.

${ }^{c} \mathrm{LMV}_{2}-\mathrm{LMV}_{4}$ : Longissimus thoracis et lumborum muscle volume between the 2 nd and the 4th lumbar vertebrae.

${ }^{\mathrm{d}} \mathrm{LMV}_{\text {tot: }}$ Longissimus thoracis et lumborum muscle total volume.

* $P<0.01$.

lower than the carcass measurements. This agrees with Mahgoub (1998) in sheep who found that LM volume measured in the carcass was higher than that obtained in vivo by RTU. Similar findings were also reported for the LM area in cattle (Greiner, Rouse, Wilson, Cundiff, \& Wheeler, 2003; Robinson, McDonald, Hammond, \& Turner, 1992), sheep (Edwards et al., 1989; Férnandez, Gallego, \& Quintanilla, 1997; Férnandez, García, Vergara, \& Gallego, 1998; Hamby, Stouffer, \& Smith, 1986; Ward, Purchas, \& Abdullah, 1992), and poultry (Silva, Pinheiro et al., 2006). Difficulties in image analysis, operator effect, and differences in muscle shape due to slaughter procedure are reasons given for the underestimation of carcass measurements by RTU. In the present study it seems reasonable to assume that the underestimation of carcass measurements can be explained by differences in muscles shape due to slaughter procedures.

The potential of LM volume measured by RTU as a predictor of carcass LM volume was high ( $r$ varied between 0.874 and $0.968 ; P<0.01)$. The lower correlation coefficient value was observed for muscle measurements taken over the 7 th thoracic vertebra. These results may reflect anatomical differences since at this site the LM muscle is inside a more complex tissue distribution than at the other sites along the thoracic/lumbar axis, particularly 2nd and 4th lumbar vertebrae (Russel, 1995; Simm, 1983), or the low absolute values of the muscle area at this site $\left(11.3 \mathrm{~cm}^{2}\right)$. However, the ultrasound equipment used, namely the probe length (64 mm), was able to accurately measure this trait allowing the assessment of differences between animals. The image analysis combined with large probes is able to give very good images and, therefore, accurate measurements are 
obtained. Previous work has shown that improvement in the predicting ability of RTU can be achieved using large probes and image analysis (McLaren et al., 1991; Silva, Afonso et al., 2006; Williams, 2002; Young \& Deaker, 1994). The length of the probe may have contributed to the good prediction ability of LM volume in our study because it allows identification of the lateral boundaries of the LM on RTU images, as observed by Stouffer (2004) in cattle and Silva, Afonso et al. (2006) in sheep.

Little information is available about LM volume determined in vivo by RTU (Mahgoub, 1998; Silva, Pinheiro et al., 2006). However, more information is available on LM volume determination using CT (Jopson et al., 1995; Kvame \& Vangen, 2006) showing high correlations between in vivo and carcass measurements in sheep $(r>0.90)$. In the present study, correlation coefficients between LM volume determined by in vivo RTU and in the carcass were higher $\left(r=0.968 ; P<0.01\right.$ for $\left.\mathrm{LMV}_{\text {tot }}\right)$ than those obtained by Mahgoub (1998) in sheep and by Silva, Pinheiro et al. (2006) in broiler chickens. Using sheep $(n=18)$, Mahgoub (1998) reported a correlation coefficient of $0.59(P<0.01)$ between LM volume measured in vivo by RTU and in the carcass. Recently, using broiler chicken $(n=103)$, Silva, Pinheiro et al. (2006) obtained a correlation coefficient of $0.866(P<0.01)$ between breast volume measured in vivo by RTU and in the carcass.

Findings of the current study show that LM volume measured in vivo by RTU is able to accurately predict carcass LM volume in sheep, confirming previous results of Mahgoub (1998).

\subsection{Estimation of carcass composition from muscle volume by simple regressions}

Simple regressions were developed to estimate carcass composition, i.e., muscle, subcutaneous fat, intermuscular fat and total fat from LM volume measured by RTU. The $R^{2}$ and the RSD of the regressions obtained for the estimations of tissue weights and proportions are presented in Tables 3 and 4, respectively.

The RTU measurements of LM volume provided reliable data to estimate carcass composition of sheep in the weight range studied. All RTU measurements of LM volume explained most of the variation of the dependent variables ( $R^{2}$ varied from 0.702 to $0.908 ; P<0.01$ ). This was particularly evident with the $\mathrm{LMV}_{2}, \mathrm{LMV}_{2}-\mathrm{LMV}_{4}$ and $\mathrm{LMV}_{\text {tot }}$ measurements to predict the amount of muscle in carcass $\left(R^{2}=0.891,0.908\right.$ and 0.887 , respectively; $\left.P<0.01\right)$.

However, RTU measurements had less ability to explain fat tissues in carcass. These results are in agreement with those obtained in previous studies with sheep (Edwards et al., 1989; Férnandez et al., 1997) using muscle area for predicting carcass composition in that they were better in predicting carcass muscle than fat.

Studies with lambs (Jopson et al., 1995; Kvame \& Vangen, 2006; Young, Nsoso, Logan, \& Beatson, 1996) using CT and swine (Collewet et al., 2005; Mitchell et al., 2001) using MRI have also shown high correlations between volume measurements and carcass traits. Determination coefficients presented on Table 3 are similar to those reported by Young et al. (1996) between LM volume determined over the 7 th thoracic vertebra and the 2 nd and 5 th lumbar vertebrae and carcass muscle and fat weights $\left(R^{2}\right.$ varied from 0.54 to 0.83 ). However, our results are better than those of Mahgoub (1998) for estimating carcass muscle with LM volume measured by RTU in sheep $\left(R^{2}=0.476\right.$; $n=18 ; P<0.01)$.

A poor fit of the data resulted when LM volume measurements were regressed against carcass composition expressed in percentage (Table $4 ; R^{2}$ varied from 0.495 to $0.625 ; P<0.01$ ), the higher determination coefficients being found for total fat. Junkuszew and Ringdorfer (2005) using

Table 3

Determination coefficients $\left(R^{2}\right)$ and residual standard deviation (RSD) of the simple regressions for the estimation of carcass muscle, subcutaneous fat, intramuscular fat and total fat weights from in vivo real-time ultrasonography measurements of sheep $(n=47)$

\begin{tabular}{|c|c|c|c|c|c|c|c|c|}
\hline \multirow[t]{2}{*}{$\operatorname{LMV}^{\mathrm{a}}\left(\mathrm{cm}^{3}\right)$} & \multicolumn{2}{|c|}{ Muscle (kg) } & \multicolumn{2}{|c|}{ Subcutaneous fat $(\mathrm{kg})$} & \multicolumn{2}{|c|}{ Intermuscular fat $(\mathrm{kg})$} & \multicolumn{2}{|c|}{ Total fat $(\mathrm{kg})$} \\
\hline & $\overline{R^{2}}$ & RSD & $\overline{R^{2}}$ & RSD & $\overline{R^{2}}$ & RSD & $\overline{R^{2}}$ & RSD \\
\hline $\mathrm{LMV}_{7}{ }^{\mathrm{b}}$ & $0.813^{*}$ & 0.76 & $0.734^{*}$ & 0.95 & $0.702^{*}$ & 0.66 & $0.727^{*}$ & 1.59 \\
\hline $\mathrm{LMV}_{9}{ }^{\mathrm{b}}$ & $0.856^{*}$ & 0.68 & $0.768^{*}$ & 0.89 & $0.751^{*}$ & 0.61 & $0.767^{*}$ & 1.48 \\
\hline $\operatorname{LMV}_{11}{ }^{\mathrm{b}}$ & $0.858^{*}$ & 0.67 & $0.772^{*}$ & 0.89 & $0.757^{*}$ & 0.61 & $0.772^{*}$ & 1.47 \\
\hline $\operatorname{LMV}_{13}{ }^{\mathrm{b}}$ & $0.856^{*}$ & 0.68 & $0.775^{*}$ & 0.88 & $0.758^{*}$ & 0.61 & $0.774^{*}$ & 1.46 \\
\hline $\mathrm{LMV}_{7}-\mathrm{LMV}_{13}{ }^{\mathrm{c}}$ & $0.853^{*}$ & 0.69 & $0.769^{*}$ & 0.89 & $0.750^{*}$ & 0.62 & $0.767^{*}$ & 1.48 \\
\hline $\mathrm{LMV}_{2}{ }^{\mathrm{b}}$ & $0.891^{*}$ & 0.60 & $0.762^{*}$ & 0.90 & $0.776^{*}$ & 0.59 & $0.773^{*}$ & 1.46 \\
\hline $\mathrm{LMV}_{4}{ }^{\mathrm{b}}$ & $0.871^{*}$ & 0.64 & $0.782^{*}$ & 0.87 & $0.775^{*}$ & 0.59 & $0.785^{*}$ & 1.43 \\
\hline $\mathrm{LMV}_{2}-\mathrm{LMV}_{4}^{\mathrm{d}}$ & $0.908^{*}$ & 0.55 & $0.794^{*}$ & 0.85 & $0.798^{*}$ & 0.56 & $0.802^{*}$ & 1.38 \\
\hline $\mathrm{LMV}_{\text {tot }}{ }^{\mathrm{e}}$ & $0.887^{*}$ & 0.61 & $0.789^{*}$ & 0.86 & $0.780^{*}$ & 0.58 & $0.791^{*}$ & 1.41 \\
\hline
\end{tabular}

a LMV: Longissimus thoracis et lumborum muscle volume.

${ }^{\text {b }} \mathrm{LMV}_{7}, \mathrm{LMV}_{9}, \mathrm{LMV}_{11}, \mathrm{LMV}_{13}, \mathrm{LMV}_{2}, \mathrm{LMV}_{4}$ : Longissimus thoracis et lumborum muscle volume above the 7 th, 9th, 11 th and 13 th thoracic vertebrae and the 2 nd and 4 th lumbar vertebrae, respectively.

${ }^{c} \mathrm{LMV}_{7}-\mathrm{LMV}_{13}$ : Longissimus thoracis et lumborum muscle volume between the 7 th and the 13 th thoracic vertebrae.

${ }^{\mathrm{d}} \mathrm{LMV}_{2}-\mathrm{LMV}_{4}$ :Longissimus thoracis et lumborum muscle volume between the 2 nd and the 4 th lumbar vertebrae.

e $\mathrm{LMV}_{\text {tot }}$ : Longissimus thoracis et lumborum muscle total volume.

* $P<0.01$. 
Table 4

Determination coefficients $\left(R^{2}\right)$ and residual standard deviation (RSD) of the simple regressions for the estimation of carcass muscle, subcutaneous fat, intramuscular fat and total fat proportions from in vivo real-time ultrasonography measurements of sheep $(n=47)$

\begin{tabular}{|c|c|c|c|c|c|c|c|c|}
\hline \multirow[t]{2}{*}{$\operatorname{LMV}^{\mathrm{a}}\left(\mathrm{cm}^{3}\right)$} & \multicolumn{2}{|c|}{ Muscle $(\%)$} & \multicolumn{2}{|c|}{ Subcutaneous fat $(\%)$} & \multicolumn{2}{|c|}{ Intermuscular fat $(\%)$} & \multicolumn{2}{|c|}{ Total fat $(\%)$} \\
\hline & $R^{2}$ & RSD & $R^{2}$ & RSD & $R^{2}$ & RSD & $R^{2}$ & RSD \\
\hline $\mathrm{LMV}_{7}{ }^{\mathrm{b}}$ & $0.543^{*}$ & 4.43 & $0.578^{*}$ & 3.81 & $0.495^{*}$ & 2.59 & $0.557^{*}$ & 6.22 \\
\hline $\mathrm{LMV}_{9}{ }^{\mathrm{b}}$ & $0.578^{*}$ & 4.30 & $0.604^{*}$ & 3.73 & $0.539^{*}$ & 2.51 & $0.591^{*}$ & 6.05 \\
\hline $\mathrm{LMV}_{11}{ }^{\mathrm{b}}$ & $0.589^{*}$ & 4.26 & $0.611^{*}$ & 3.70 & $0.547^{*}$ & 2.50 & $0.598^{*}$ & 6.01 \\
\hline $\mathrm{LMV}_{13}{ }^{\mathrm{b}}$ & $0.588^{*}$ & 4.27 & $0.615^{*}$ & 3.69 & $0.550^{*}$ & 2.49 & $0.602^{*}$ & 5.99 \\
\hline $\mathrm{LMV}_{7}-\mathrm{LMV}_{13}{ }^{\mathrm{c}}$ & $0.580^{*}$ & 4.30 & $0.607^{*}$ & 3.71 & $0.539^{*}$ & 2.51 & $0.593^{*}$ & 6.04 \\
\hline $\mathrm{LMV}_{2}^{\mathrm{b}}$ & $0.590^{*}$ & 4.26 & $0.597^{*}$ & 3.75 & $0.568^{*}$ & 2.45 & $0.598^{*}$ & 6.01 \\
\hline $\mathrm{LMV}_{4}^{\mathrm{b}}$ & $0.603^{*}$ & 4.21 & $0.619^{*}$ & 3.67 & $0.565^{*}$ & 2.46 & $0.611^{*}$ & 5.94 \\
\hline $\mathrm{LMV}_{2}-\mathrm{LMV}_{4}{ }^{\mathrm{d}}$ & $0.614^{*}$ & 4.17 & $0.625^{*}$ & 3.65 & $0.583^{*}$ & 2.42 & $0.622^{*}$ & 5.87 \\
\hline $\mathrm{LMV}_{\text {tot }} \mathrm{e}$ & $0.602^{*}$ & 4.21 & $0.623^{*}$ & 3.66 & $0.565^{*}$ & 2.46 & $0.613^{*}$ & 5.93 \\
\hline
\end{tabular}

a LMV: Longissimus thoracis et lumborum muscle volume.

${ }^{\mathrm{b}} \mathrm{LMV}_{7}, \mathrm{LMV}_{9}, \mathrm{LMV}_{11}, \mathrm{LMV}_{13}, \mathrm{LMV}_{2}, \mathrm{LMV}_{4}$ : Longissimus thoracis et lumborum muscle volume above the 7 th, 9 th, 11 th and 13 th thoracic vertebrae and the 2 nd and 4 th lumbar vertebrae, respectively.

${ }^{c} \mathrm{LMV}_{7}-\mathrm{LMV}_{13}$ : Longissimus thoracis et lumborum muscle volume between the 7 th and the 13 th thoracic vertebrae.

${ }^{\mathrm{d}} \mathrm{LMV}_{2}-\mathrm{LMV}_{4}$ :Longissimus thoracis et lumborum muscle volume between the 2 nd and the 4 th lumbar vertebrae.

${ }^{\mathrm{e}} \mathrm{LMV}_{\text {tot }}$ : Longissimus thoracis et lumborum muscle total volume.

${ }^{*} P<0.01$.

RTU measurements (thickness) in male lambs $(n=41)$ also found that muscle and fat contents of the carcass were estimated with high accuracy when expressed in absolute amounts $(\mathrm{kg})$ instead of proportions $(\%) R^{2}=0.62$ and 0.58 for fat and $R^{2}=0.67$ and 0.50 for muscle, expressed in $\mathrm{kg}$ and in \%, respectively.

The best estimates of carcass tissue weights and proportions were obtained using the $\mathrm{LMV}_{2}-\mathrm{LMV}_{4}$ for all tissues studied. However, as mentioned above, the $R^{2}$ values were lower for the estimation of tissue proportions.

These results indicate that the estimation of volume by RTU may be confidently used to estimate carcass composition. The correlations between LM volume and carcass composition and the accurate estimate of carcass LM vol- ume by RTU emphasizes the usefulness of this ultrasound measurement to predict carcass tissue weights and proportions in sheep.

\subsection{Estimation of carcass composition from muscle volume by multiple regressions}

Several studies with sheep (Delfa, Teixeira, Gonzalez, \& Blasco, 1995; Kempster, Arnall, Alliston, \& Blarker, 1982) have shown that LW combined with RTU measurements increases the predicting ability of carcass composition, at minimal cost. Since the practical use of RTU measurements for prediction of carcass composition is an important goal, multiple equations were developed to estimate

Table 5

Multiple regression equations for predicting weights and proportions of muscle, subcutaneous fat, intermuscular fat and total fat of sheep carcass using live weight (LW) and Longissimus thoracis et lumborum muscle volume (LMV) measured in vivo by real-time ultrasonography $(n=47)$

\begin{tabular}{|c|c|c|c|c|c|c|c|c|c|c|}
\hline \multirow[t]{2}{*}{ Tissue } & \multirow[t]{2}{*}{$\mathrm{Cp}^{\mathrm{a}}$} & \multirow[t]{2}{*}{$R^{2}$} & \multirow[t]{2}{*}{$\mathrm{RSD}^{\mathrm{b}}$} & \multirow[t]{2}{*}{ Intercept } & \multicolumn{6}{|c|}{ Coefficients of the equations variables } \\
\hline & & & & & $\overline{L W}$ & $\mathrm{LMV}_{9}{ }^{\mathrm{c}}$ & $\mathrm{LMV}_{13}{ }^{\mathrm{c}}$ & $\mathrm{LMV}_{2}{ }^{\mathrm{c}}$ & $\mathrm{LMV}_{4}{ }^{\mathrm{c}}$ & $\mathrm{LMV}_{2}-\mathrm{LMV}_{4}^{\mathrm{d}}$ \\
\hline \multicolumn{11}{|l|}{ Weight ( $k g$ ) } \\
\hline Muscle & 1.29 & $0.916^{*}$ & 0.531 & 3.29 & 60.60 & - & - & - & - & 22.79 \\
\hline Subcutaneous fat & 2.23 & $0.871^{*}$ & 0.702 & -5.27 & 197.48 & - & 32.04 & -33.15 & - & - \\
\hline Intermuscular fat & 3.87 & $0.866^{*}$ & 0.474 & -2.54 & 98.41 & - & -9.57 & - & 17.51 & - \\
\hline Total fat & 3.34 & $0.867^{*}$ & 1.134 & -8.33 & 327.60 & - & - & -52.68 & 48.07 & - \\
\hline \multicolumn{11}{|l|}{ Proportion (\%) } \\
\hline Muscle & 0.53 & $0.702^{*}$ & 3.845 & 78.8 & -0.71 & - & - & 0.14 & - & - \\
\hline Subcutaneous fat & 1.04 & $0.741^{*}$ & 3.289 & -8.03 & 0.69 & -0.81 & 0.70 & -0.15 & - & - \\
\hline Intermuscular fat & 2.74 & $0.677^{*}$ & 2.232 & -1.75 & 0.43 & - & - & -0.05 & - & - \\
\hline Total fat & 0.91 & $0.712^{*}$ & 5.307 & -9.02 & 1.14 & - & - & -0.14 & - & - \\
\hline
\end{tabular}

${ }^{\mathrm{a}} \mathrm{Cp}$ : Mallows statistic.

b RSD: residual standard deviation.

${ }^{\mathrm{c}} \mathrm{LMV}_{9}, \mathrm{LMV}_{13}, \mathrm{LMV}_{2}, \mathrm{LMV}_{4}$ : Longissimus thoracis et lumborum muscle volume above the 9 th and the 13th thoracic vertebrae, the $2 \mathrm{nd}$ and the 4 th lumbar vertebrae, respectively.

${ }^{\mathrm{d}} \mathrm{LMV}_{2}-\mathrm{LMV}_{4}$ :Longissimus thoracis et lumborum muscle volume between the $2 \mathrm{nd}$ and the 4 th lumbar vertebrae.

${ }^{*} P<0.01$. 
carcass composition from LM volume determined after RTU measurements and LW.

The best prediction equations generated by the stepwise procedure for muscle, subcutaneous fat, intermuscular fat and total fat in carcasses using LW and LM volume measured by RTU are presented in Table 5. For all traits, the best fit was obtained with two, three or four independent variables. Amounts (weights and proportions) of muscle, subcutaneous fat, intermuscular fat and total fat are accurately predicted $\left(R^{2}>0.866\right.$ for weights and $R^{2}>0.677$ for proportions; $P<0.01$ ). For all tissues, the stepwise procedure was consistent in selecting LW to establish the tissue prediction equations.

The inclusion of LW in these equations was expected because LW usually well explains the carcass tissue variations, and within a sex, LW is the main determinant of the amount of fat and muscle. The LW contribution to explaining variation in carcass composition was also observed in previous studies with sheep (Férnandez et al., 1998; Silva et al., 2005; Teixeira et al., 2006; Young et al., 1996) as well as other species (cattle: Greiner et al., 2003; swine: Gresham, McPeake, Bernard, \& Henderson, 1992; broiler chickens: Silva, Pinheiro et al., 2006).

The high accuracy of estimation of muscle in the carcass from only 1, 2 or 3 LM volume measurements, less than the number proposed by Thompson and Kinghorn (1992) for CT (between 10 and 15), can be explained on the assumption that the shape of this muscle is close to a cylinder and thus the number of sections obtained during a scanning session can be reduced. These findings agree with those of Young et al. (1996), Young, Nsoso, and Beatson (1999) and Kvame and Vangen (2006). Young et al. (1999) showed that LW and tissue areas from three scans accounted for $96 \%, 98 \%$ and $89 \%$ of the variations in total weight of muscle, fat and bone, respectively, in the carcasses of Suffolk lambs.

\section{Conclusions}

This study has shown that LM volume measurements taken in vivo are highly related to the corresponding carcass measurements. Carcass composition (muscle and fat) can be accurately predicted using LM volume measured in vivo by RTU from 1, 2 or 3 scans and LW.

Results from this study encourage the use of LM volume measured in vivo by RTU for the estimation of carcass composition since the procedure rapidly yields a threedimensional measurement of the LM. This approach is non-invasive, accurate, reliable, and easy to use and only requires an inexpensive RTU machine. Moreover, such measurements in everyday practice are easy to obtain due to the mobility of the equipment.

\section{Acknowledgement}

This work received financial support from the Fundação para a Ciência e Tecnologia (FCT) - Project SAPI-
ENS - POCTI/1999/CVT/36259 which we gratefully acknowledge.

\section{References}

Baulain, U. (1997). Magnetic resonance imaging for the in vivo determination of body composition in animal science. Computers and Electronics in Agriculture, 17, 189-203.

Collewet, G., Bogner, P., Allen, P., Busk, H., Dobrowolski Olsen, E., et al. (2005). Determination of the lean meat percentage of pig carcasses using magnetic resonance imaging. Meat Science, 70, $563-572$.

Delfa, R., Teixeira, A., Gonzalez, C., \& Blasco, I. (1995). Ultrasonic estimates of fat thickness and Longissimus dorsi muscle depth for predicting carcass composition of the Aragon lambs. Small Ruminant Research, 16, 159-164.

Edwards, J. W., Cannell, R. C., Garrett, R. P., Savell, J. W., Cross, H. R., \& Longnecker, M. T. (1989). Using ultrasound, linear measurements and live fat thickness estimates to determine the carcass composition of market lambs. Journal of Animal Science, 67, 3322-3330.

Férnandez, C., Gallego, L., \& Quintanilla, A. (1997). Lamb fat thickness muscle area measured by a computerized ultrasonic system. Small Ruminant Research, 26, 277-282.

Férnandez, C., García, A., Vergara, H., \& Gallego, L. (1998). Using ultrasound to determine fat thickness and longissimus dorsi area on Manchego lambs of different live weight. Small Ruminant Research, 27, $159-165$.

Fisher, A. V., \& De Boer, H. (1994). The EAAP standard method of sheep carcass assessment. Carcass measurements and dissection procedures. Report of the EAAP working group on carcass evaluation, in cooperation with the CIHEAM Instituto Agronomico Mediterraneo of Zaragoza and the CEC Directorate General for Agriculture in Brussels. Livestock Production Science, 38, 149-159.

Fortin, A. (1980). Fat thickness measured with three ultrasonic instruments on live ram lambs as predictors of cutability. Canadian Journal of Animal Science, 60, 857-867.

Fuller, M. F., Fowler, P. A., McNeill, G., \& Foster, M. A. (1994). Imaging techniques for the assessment of body composition. Journal of Nutrition, 124, 1546S-1550S.

Greiner, S. P., Rouse, G. H., Wilson, D. E., Cundiff, L. V., \& Wheeler, T. L. (2003). The relationship between ultrasound measurements and carcass fat thickness and longissimus muscle area in beef cattle. Journal of Animal Science, 81, 676-682.

Gresham, J. D., McPeake, S. R., Bernard, J. K., \& Henderson, H. H. (1992). Commercial adaptation of ultrasonography to predict pork carcass composition from live animal and carcass measurements. Journal of Animal Science, 70, 631-639.

Hamby, P. L., Stouffer, J. R., \& Smith, S. B. (1986). Muscle metabolism and real-time ultrasound measurement of muscle and subcutaneous adipose tissue growth in lambs fed diets containing a beta-agonist. Journal of Animal Science, 63, 1410-1417.

Hopkins, D. L., Pirlot, K. L., Roberts, A. H. K., \& Beattie, A. S. (1993). Changes in fat depths and muscle dimensions in growing lambs as measured by real-time ultrasound. Australian Journal of Experimental Agriculture, 33, 707-712.

Jopson, N. B., Kolstad, K., Sehested, E., \& Vangen, O. (1995). Computed tomography as an accurate and cost effective alternative to carcass dissection. Proceedings of the Australian Association of Animal Breeding and Genetics, 11, 635-638.

Junkuszew, A., \& Ringdorfer, F. (2005). Computer tomography and ultrasound measurements as methods for the prediction of the body composition of lambs. Small Ruminant Research, 56, 121-125.

Kempster, A. J., Arnall, D., Alliston, J. C., \& Blarker, J. D. (1982). An evaluation of two ultrasonic machines (Scanogram Danscaner) for predicting the body composition of live sheep. Animal Production, 34, $249-255$. 
Korn, V., Sr., Baulain, U., Arnold, M., \& Brade, W. (2005). Nutzung von magnet-resonanz-tomographie und ultraschall-technik zur bestimmung des schlachkörperwertes beim schaf. Zuchtungskunde, 77, 382-393.

Kvame, T., \& Vangen, O. (2006). In-vivo composition of carcass regions in lambs of two genetic lines, and selection of CT positions for estimation of each region. Small Ruminant Research, 66, 201-208

MacNeil, M. D. (1983). Choice of a prediction equation and the use of the selected equation in subsequent experimentation. Journal of Animal Science, 57, 1328-1336.

Mahgoub, O. (1998). Ultrasonic scanning measurements of the Longissimus thoracis et lumborum muscle to predict carcass muscle content in sheep. Meat Science, 48, 41-48.

McEwan, J. C., Clarke, J. N., Knowler, M. A., \& Wheeler, M. (1989). Ultrasonic fat depths in Romney lambs and hoggets from lines selected for different production traits. Proceedings of the New Zealand Society of Animal Production, 49, 113-119.

McLaren, D. G., Novakofski, J., Parrett, D. F., Lo, L. L., Singh, S. D., Neumann, K. R., et al. (1991). A study of operator effects on ultrasonic measurements of fat and longissimus muscle area in cattle, sheep and pigs. Journal of Animal Science, 69, 54-66.

Mitchell, A. D., Scholz, A. M., Wange, P. C., \& Song, H. (2001). Body composition analysis of the pig by magnetic resonance imaging Journal of Animal Science, 79, 1800-1813.

NRC (1985). Nutrient requirements of sheep (6th revised ed.). Washington, DC: National Academic Press.

Robinson, D. L., McDonald, C. A., Hammond, K., \& Turner, J. W (1992). Live animal measurement of carcass traits by ultrasound: Assessment and accuracy of sonographers. Journal of Animal Science, 70, 1667-1676.

Russel, A. J. F. (1995). Ultrasonography and body composition in sheep. In P. J. Goddard (Ed.), Veterinary ultrasonography (pp. 315-323). Wallingford, UK: CAB International.

Shelton, M., Smith, G. C., \& Orts, F. (1977). Predicting carcass cutability of Rambouillet rams using live animal traits. Journal of Animal Science, 44, 333-337.

Silva, S. R., Gomes, M. J., Dias-da-Silva, A., Gil, L. F., \& Azevedo, J. M T. (2005). Estimation in vivo of the body and carcass chemical composition of growing lambs by real-time ultrasonography. Journal of Animal Science, 83, 350-357.

Silva, S. R., Pinheiro, V., Guedes, C. M., \& Mourão, J. L. (2006). Prediction of carcass and breast weights and yields in broiler chickens using breast volume determined in vivo by real-time ultrasonic measurement. British Poultry Science, 47, 694-699.

Silva, S. R., Afonso, J. J., Santos, V. A., Monteiro, A., Guedes, C. M., Azevedo, J. M. T., et al. (2006). In vivo estimation of sheep carcass composition using real time ultrasound with two probes of 5 and 7.5 MHz and image analysis. Journal of Animal Science, 84, 3433-3439.

Simm, G. (1983). The use of ultrasound to predict the carcass composition of live cattle - a review. Animal Breeding Abstracts, 51, 853-875.

Stouffer, J. R., Wallentine, M. V., Wellington, G. H., \& Diekmann, A. (1961). Development and application of ultrasonic methods for measuring fat thickness and rib-eye area in cattle and hogs. Journal of Animal Science, 20, 759-767.

Stouffer, J. R. (2004). History of ultrasound in animal science. Journal Ultrasound Medicine, 23, 577-584.

Szabo, Cs., Babinszky, L., Verstegen, M. W. A., Vangen, O., Jansman, A. J. M., \& Kanis, E. (1999). The application of digital imaging techniques in the in vivo estimation of body composition of pigs: A review. Livestock Production Science, 60, 1-11.

Teixeira, A., Matos, S., Rodrigues, S., Delfa, R., \& Cadavez, V. (2006). In vivo estimation of lamb carcass composition by real-time ultrasonography. Meat Science, 74, 289-295.

Thompson, J., \& Kinghorn, B. (1992). CATMAN - A program to measure CAT scans for prediction of body components in live animals. $<$ http://ansc.une.edu.au/catscan/australia/1992/ $>$.

Ward, B. G., Purchas, R. W., \& Abdullah, A. Y. (1992). The value of ultrasound in assessing the leg muscling of lambs. Proceedings of the New Zealand Society of Animal Production, 52, 33-36.

Williams, A. R. (2002). Ultrasound applications in beef cattle carcass research and management. Journal of Animal Science, 80(E. Suppl. 2), E183-E188.

Young, M. J., \& Deaker, J. M. (1994). Ultrasound measurements predict estimate adipose and muscle weights better than carcass measurements. Proceedings of the New Zealand Society of Animal Production, 54, 215-217.

Young, M. J., Nsoso, S. J., Logan, C. M., \& Beatson, P. R. (1996). Prediction of carcass tissue in vivo using weight, ultrasound or X-ray CT measurements. Proceedings of the New Zealand Society of Animal Production, 56, 205-211.

Young, M. J., Nsoso, S. J., \& Beatson, P. R. (1999). Response to selection for lean tissue growth in sheep as assessed by X-ray computer tomography. Wool Technology and Sheep Breeding, 47, 34-37. 